To cite: I Shai 'The right to development, transformative constitutionalism and radical transformation in South Africa: Post-colonial and de-colonial reflections' (2019) 19 African Human Rights Law Journal 494-509

http://dx.doi.org/10.17159/1996-2096/2019/v19n1a23

\title{
The right to development, transformative constitutionalism and radical transformation in South Africa: Post-colonial and de-colonial reflections
}

\author{
Isaac Shai* \\ Postdoctoral Fellow, Thabo Mbeki African Leadership Institute, University of \\ South Africa \\ https://orcid.org/0000-0001-7686-8306
}

\begin{abstract}
Summary
This article suggests that currently insufficient theorisation exists of what should constitute radical transformation in South Africa and whether the discourse on transformative constitutionalism and the right to development are capable of living up to the expectations of radical transformation. The point of departure should be radical transformation which in turn must inform the content of both transformative constitutionalism and the right to development. The central question that the article explores is whether the notion of transformative constitutionalism, read in conjunction with and as the concretisation of the right to development, has the capacity to bring about radical transformation in South Africa.
\end{abstract}

Key words: radical transformation; transformative constitutionalism; post-colonial theory; de-colonial theory; right to development

BA LLB (Witwatersrand) LLM (UNISA) LLD (Pretoria). This article is based on a paper titled 'The right to development, transformative constitutionalism and radical transformation in South Africa: Post-colonial and de-colonial reflections' delivered at the 2nd International Conference on the Right to Development, 15-17 August 2018, University of Pretoria, South Africa. 


\section{Introduction}

Borrowing from Deleuze's The logic of sense, Mbembe narrates a representation of Africa that is 'constituted by a paradox'. ${ }^{1}$ Mbembe narrates this paradox allegorically in the form of an Africa that is a figure with 'the highest power of language' and an Africa that represents 'the impotence of the speaker' who is unable to 'state the sense' of what he or she says, and unable to say at the 'same time something and its meaning' ${ }^{2}$ For Mbembe, Africa paradoxically is the speaker endowed with the power of language but whose impotence as a speaker prevents him or her to 'say something and its meaning'.

The speaker is prostrate and thus impotent due to what Mudimbe calls the 'colonising structure' which essentially is a grotesque colonial act that manifested itself in the domination of African space, the reformation of the native's mind and the integration of African local economic histories into Western perspectives. ${ }^{3}$ For Bhabha the impotence of the speaker who at the same time possesses the highest power of language can be traced to 'colonial dislocation, its displacement of time and person, its defilement of culture and territory'. ${ }^{4}$ The question that necessarily arises is how Africa can seize this highest power of language that it possesses so as to overcome its prostrate position.

I propose that the notion of radical transformation offers an alternative prism and space for Africa to speak with potency. Although the notion of multiple and variegated colonialisms in Africa is an apposite descriptor, I suggest that South Africa currently serves as an appropriate paradoxical representation of Mbembe's allegorical 'impotent speaker' in that the country possesses the 'best' and 'progressive' Constitution, yet the same Constitution presides over a multitude of maladies. Specifically, the choice of South Africa is based on three main reasons. First, I regard South Africa as both a touchstone and an apogee of that which is at once present and yet absent. In other words, South Africa arguably is a pungent representation of Mbembe's figure that is possessed of the highest power of language and yet represents the impotence of the speaker that is unable to state the sense of what he or she says, and unable at the same time to 'say something and its meaning'. Put differently, the possibilities of a radically better life for all exist, but the same possibilities are continuously foreclosed and this foreclosure is due to the second reason for selecting South Africa. The second reason for the choice of South Africa is influenced by Mudimbe's assertion that South Africa is emblematic of the colonising structure in its most

A Mbembe Critique of black reason trans L Dubois (2017) 52.

As above.

As above.

4 H Bhabha 'Foreword to the 1986 edition' in F Fanon Black skin white masks trans L Markmann (1967) xxii. 
extreme manifestation. ${ }^{5}$ It is the colonising structure that I suggest is insidiously responsible for this foreclosure. Third, what is forebodingly missing in South Africa is a discourse on radical transformation that eschews historicism, positivism and the notion of a single indivisible truth about the nature of change required to make Africa a better place. The attainment of radical transformation in South Africa is often spoken of as a possibility within the context of Western liberal democracy. Put differently, there is a sense in which it is hoped that Western liberal democracy is capable of bringing about radical transformation because the South African Constitution a priori is transformative. The possibility of attaining radical transformation within the context of Western liberal democracy negates the fact that

European liberalism was forged in parallel with imperial expansion. It was in relation to expansion that liberal political thought in Europe confronted such questions as universalism, individual rights, the freedom of exchange, the relationship between means and ends, the national community and political capacity. ${ }^{6}$

In other words, 'the coming of modernity coincided with the appearance of race and the latter's slow transformation into the privileged matrix for techniques of domination, yesterday as today'. 7 Therefore, the idea of radical transformation that I propose can only bring about rupture in that it seeks to avoid re-inscribing the very historicism and positivism that are embedded within the structures of Western liberal democracy. In this sense the question then becomes whether the discourse on transformative constitutionalism and the right to development are capable of living up to the expectations of radical transformation. There is a sense in which the notions of radical transformation, transformative constitutionalism and the right to development tend to be perceived as meaning one and the same thing. My argument is that the point of departure should be radical transformation which in turn must inform the content of both transformative constitutionalism and the right to development.

However, any theorisation of radical transformation should at the very least reckon with the fact that while the impact of colonialism and apartheid ultimately is felt through material dispossession and raw economic exploitation, the more devastating, corrosive and longlasting impact of colonialism continues to be ontological and epistemic. As Chatterjee states, '[i]t is not just military might or industrial strength, but thought itself, which can dominate and subjugate' 8 The greatest achievement of colonial modernity has been its mythical pretentions of the impossibility of other 'truths' and its violent suppression of other possible realities. Viewed from this prism,

5 VY Mudimbe The invention of Africa: Gnosis, philosophy and the order of knowledge (1988) 6.

6 Mbembe (n 1) 55.

7 As above.

8 P Chatterjee Nationalist thought and the colonial world: A derivative discourse (1986) 11. 
radical transformation cannot be viewed as a particular end state but rather as a state of becoming that begins with the disruption and 'provincialisation' of Western modernity. The central question is whether the notion of transformative constitutionalism, read in conjunction with or as a concretisation of the right to development, has the capacity to bring about radical transformation in South Africa.

In exploring the capacity of transformative constitutionalism and the right to development to bring about radical transformation, I propose to first read the notion of radical transformation from postcolonial and de-colonial theoretical approaches. I contend that radical transformation, viewed from the prism of post-colonial and decolonial theoretical approaches, fundamentally inheres in the disruption of coloniality. Second, I propose to analyse the two notions of transformative constitutionalism and the right to development from the prism of post-colonial and de-colonial theoretical approaches. Third, I propose to deal with post-colonial and de-colonial approaches to law. A reading of law from the post-colonial and de-colonial approaches casts doubt on the ability of transformative constitutionalism and the right to development to disrupt coloniality and thus bring about radical transformation. However, I do acknowledge that both the notions of transformative constitutionalism and the right to development constitute progressive, albeit insufficient, interventions towards the realisation of radical transformation.

\section{De-coloniality, post-coloniality and radical transformation}

I suggest that a dynamic interaction between de-colonial and postcolonial theory has the potential to clarify and shore up what should, at a minimum, constitute radical transformation, not only in South Africa but on the African continent as a whole. This view is echoed by Mignolo when he states the following: ${ }^{9}$

I do not see de-coloniality and post-coloniality campaigning for election to win the voting competition that decides which is the best, but as complementary trajectories with similar goals of social transformation. Both projects strive to unveil colonial strategies promoting the reproduction of subjects whose aims and goals are control and possess ... In any event, the post-colonial and the de-colonial are two different projects that have in common the concern with colonialism, colonial legacies.

For Bhambra both de-colonial and post-colonial approaches challenge European historical narratives and historiographical traditions and forcefully bring to bear the parochial character of European origins of modernity and, most importantly, the intrinsic connection between

9 W Mignolo The darker side of Western modernity: Global futures, de-colonial options (2011) xxvi- xxvii. 
modernity and colonialism, empire and enslavement. ${ }^{10}$ Lowman and Mayblin are of the view that both theoretical approaches ably expose the universalising pretentions that hitherto have characterised European Western philosophy from the Enlightenment period onwards. 11

As a prelude to post-colonial and de-colonial approaches to radical transformation, it should have recalled that both approaches have also made incisive analytical interventions on the impact of colonialism and apartheid on the African continent. For instance, De Sousa Santos has stated that 'while the political dimension of colonial intervention has been widely criticised, the burden of the colonial epistemic monoculture is still accepted nowadays as a symbol of development and modernity'. ${ }^{12}$ Despite these interventions on the impact of colonialism in Africa, an incessant maelstrom continues to bedevil discussions on the impact of colonialism. What compounds matters is that even those who continue to battle the effects of colonialism and the continuing impact of neo-colonialism end up inadvertently embracing the subjects of their critique. The dominant discourse on change, embraced by some Africans, continues to pungently reflect teleological approaches that view 'progress' as 'catching up' with Western Europe and the United States of America. Current debates around the notion of decolonisation have only served to muddle the situation. It is in this context that we need to constantly conduct what Spivak calls a 'persistent dredging operation' on the actual impact of colonialism in order to avoid the reproduction of neo-colonial knowledge which has a tendency of treating colonialism/imperialism as evanescent. ${ }^{13}$

\subsection{Impact of colonialism}

The critical point to be made is that colonialism colonised bodies, minds, time and space. In this sense the exclusions generated by colonialism and its 'civilising paradigm' not only were of a political, economic and social nature but also of a cultural and epistemological nature. ${ }^{14}$ The aggregate results, succinctly articulated by Nandy in The intimate enemy: Loss and recovery of self under colonialism, was that colonialism 'generated the concept of the modern West from a geographical and temporal entity to a psychological category. The West is now everywhere, within the West and outside; in structures

10 G Bhambra 'Post-colonial and de-colonial dialogues' (2014) 17 Postcolonial Studies 115.

11 E Lowman \& L Mayblin (eds) 'Theorising the post-colonial, de-colonial theory' (2011) 19 Studies in Social and Political Thought 3.

12 B de Sousa Santos et al 'Opening up the canon of knowledge and recognition of difference' in B de Sousa Santos (ed) Another knowledge is possible: Beyond northern epistemologies (2007) xxxiii.

13 GC Spivak $A$ critique of post-colonial reason: Towards a history of the vanishing present (1999)1.

14 De Sousa Santos (n 12) x. 
and in mind.' 15 The consequences of what Slemon ${ }^{16}$ calls 'flag independence', which is a reference to the survival of colonialism after the demise of the empire, is that even today, because of the presence of the West everywhere, neo-colonialism is used to justify colonialism. ${ }^{17}$ The sepulchral tones that this 'presence of the West everywhere' generates is that there is no alternative to the West. This sort of epistemic violence insidiously induces and reproduces selfextermination of possible vistas on the side of the oppressed and the excluded and consistently generates and regenerates an ethnographic mythical notion of one truth for humanity. This ethnographic mythical notion of one single indivisible truth for all of humanity, states Fitzpatrick, has its genesis in the formation of occidental being: ${ }^{18}$

Occidental being is impelled in a progression away from aberrant origins. It is formed in the comprehensive denial of the 'other' - in assertions of universal knowledge, imperious judgement and encompassing being. Since it is constructed in negation, in terms of what it is not, this being is unbounded and able mythically to reconcile its particular and contingent existence with its appropriation of the universal.

The occidental defines itself by negation, conceals its particular and contingent existence and then appropriates the universal. In this sense 'the other is not truly other. It does not exist primarily ... from its relation to a West which encompasses it. The other, in its uncivilised or pre-modern state, is a construct of the West. ${ }^{19}$ We recall De Sousa Santos's incisive analysis to the effect that 'the production of the West as hegemonic knowledge required the creation of another, constituted as an intrinsically disqualified being, a collection of characteristics that were markers of inferiority'. ${ }^{20}$

This closure of other possible vistas is effected in this manner. The other that is not occidental, therefore, is forced to exist and find 'truth' within the meaning of 'truth' already constructed. The ability to speak against this 'truth' is truly foreclosed because of the 'West's arrogation to itself of truth as singular yet universal' ${ }^{21}$ and transcendental. Other possible forms of knowledge and cosmologies in this sense are effectively silenced. The mythology of Western modernity is imperiously sustained by the ontological, epistemological and physical violence of imperialism. What is true and what is not true, what is possible, what is good and what is bad therefore is determined in terms of Western rationality.

\footnotetext{
15 A Nandy The intimate enemy: Loss and recovery of self under colonialism (1983) xi.

16 S Slemon 'Post-colonial critical theories' in G Castle (ed) Post-colonial discourses: An anthology (2001) 102.

17 Nandy (n 15) xi.

18 P Fitzpatrick The mythology of modern law (1992) $\mathrm{x}$.

19 Fitzpatrick (n 18) 30.

20 De Sousa Santos (n 12) xxxv.

21 Fitzpatrick (n 18) 30.
} 
The mythology of Western modernity is further sustained by what Davis calls the notion of 'history as already determined'. ${ }^{22}$ Davis refers to this notion of 'history as already determined' as 'periodisation'. The idea of periodisation, according to Davis,

derives its explanatory power from economic models of periodisation by aligning a transition from ecclesiastical to secular society with a transition from medieval, rural, agrarian economy to a modern, urban commercial economy, most typically expressed as the transition from feudalism to capitalism.

I suggest that this idea of periodisation generates sub-notions of progress and development. It is recalled, in parenthesis, and drawing from Pellicani, ${ }^{24}$ that Karl Marx's notion of 'the dialectic' remains intrinsic to 'Hegelian theodicy' in that thinking dialectically for Marx means 'to see reality as a fragmented totality longing to regain its original unity'. ${ }^{25}$ Theodicy is view of history where freedom is progressively achieved and all that is evil gradually fades away.

Because of Eurocentrism's tendency to define itself by negation, the invented 'savage' 'ought' also to undergo a process of continuous negation by negating its previous savage existence. That the West has negated its past and that the 'savage' must also negate its savage past becomes proof enough that existence always is characterised by a movement from simplicity towards complexity which in concrete terms means a movement from the feudal, sacred, agrarian to the modern, urban and commercial (capitalism). In this sense the notion of periodisation inculcates the belief and desire to reach the ultimate and final period which is characterised by a modern, urban, commercial and capitalist society. At the centre of the notion of periodisation is Hegelian theodicy which is sustained by Marx's dialectical method.

Occidental being and its seemingly benign vectors continue to be pivotal in ensuring that the colonised constantly assume that they are on an onward march to the 'end of history' where they can also regard themselves and be regarded by those who colonised them as having finally reached the 'universal' state of development. This, I suggest, is the most profound impact that colonialism has had on the colonised. If, as Mbembe suggests, (South) Africa is possessed of the highest power of speech, one of the available avenues of ensuring the inversion of the impotent speaker is through the reading of radical transformation from the post-colonial and de-colonial approaches.

22 K Davis Periodisation and sovereignty: How ideas of feudalism and secularisation govern the politics of time (2008) 1.

23 Davis (n 22) 1-2.

$24 \mathrm{~L}$ Pellicani The genesis of capitalism and the origins of modernity (1994).

25 Pellicani (n 24) fn 3. 


\subsection{Post-colonial and de-colonial on radical transformation}

While the immediate impact of colonialism and apartheid is felt through material penury, land dispossession and racism or raw economic and political power, the more devastating, corrosive and intransigent impact of colonialism is ontological and epistemic. Due to ontological and epistemic violence, colonialism not only disrupted a particular way of African life but, most importantly, it continues to suppress and marginalise possible new vistas.

It is in this sense that the radicalism of the confluence between post-colonialism and de-colonial theories inheres in their ability to 'unveil colonial strategies promoting the reproduction of subjects whose aims and goals are control and possess'. ${ }^{26}$ As Nandy states, 'the crudity and inanity of colonisation are principally expressed in the sphere of psychology and ... in the sphere of political psychology'.27 According to De Sousa Santos: ${ }^{28}$

Proposals for radical democracy - which point towards post-capitalist horizons - and the proposal for decolonising knowledge and power which point towards post-colonial horizons - will be feasible only if the dominant epistemology is subject to a critique allowing for the emergence of epistemological options that give credibility to the forms of knowledge that underlie those proposals.

Radical transformation of the African continent therefore inheres or becomes a possibility with the disruption of coloniality. MaldonadoTorres describes coloniality as follows: ${ }^{29}$

Coloniality is different from colonialism. Colonialism denotes a political and economic relation in which sovereignty of a nation or a people rests on the power of another nation, which makes such a nation an empire. Coloniality, instead, refers to long standing patterns of power that emerged as a result of colonialism, but define culture, labour, inter-subjective relations, and knowledge production well beyond the strict limits of colonial administrations. Thus coloniality survives colonialism. It is maintained alive in books, in the criteria for academic performance, in cultural patterns, in common sense, in the self-image of peoples, in aspirations of self, and in so many aspects of our modern experience. In a way, as modern subjects we breathe coloniality all the time and every day.

Radical transformation, therefore, starts with challenging European historical narratives and historiographical traditions so as to demonstrate the parochial character of ethnographic European origins of modernity and the deep connection between modernity and colonialism, empire and enslavement. ${ }^{30}$ It is about changing the terms of the conversation and challenging 'the hegemonic ideas of what knowledge and understanding are and consequently what

26 Mignolo (n 9).

27 Nandy (n 15) 2.

28 De Sousa Santos (n 12) xxi.

29 N Maldonado-Torres 'On the coloniality of being: Contributions to the development of a concept' (2007) 21 Cultural Studies 243. 
economy, ethics and philosophy, technology and organisation of society should be'. ${ }^{31}$

It is precisely this point that takes us to the critique of and challenges facing the notions of transformative constitutionalism and the right to development. Central to my concern is whether transformative constitutionalism and the right to development address the crudity and inanity of colonialism which is located in the psychology of the oppressed, or whether they, in trying to deal with the mutation of colonialism, end up perpetuating the subject of their critique.

\section{Transformative constitutionalism and the right to development in South Africa}

The notions of transformative constitutionalism and the right to development have no limpid textual presence in the South African Constitution. However, their continued cogency may be said to derive from both the brutal colonial and apartheid past and the supposed 'newness' that the Constitution presents. Transformative constitutionalism has its origins in Klare's influential article titled 'Legal culture and transformative constitutionalism'. ${ }^{32}$ In this article Klare describes transformative constitutionalism as entailing

a long-term project of constitutional enactment, interpretation and enforcement ... to transforming a country's political social institutions and power relations in a democratic, participatory and egalitarian direction. Transformative constitutionalism connotes an enterprise of inducing largescale $e_{3}$ social change through non-violent political processes grounded in law. ${ }^{33}$

Embedded in the logic of transformative constitutionalism is the assumption of the potential for law to resolve the legacies of colonialism and apartheid. On the other hand, the idea of development as a right generally is attributed to Doudou Thiam, the former Minister of Foreign Affairs, in Algiers in 1967, and to Kéba M'baye in $1972 .{ }^{34}$ While the former coined development as human right in a diplomatic arena, ${ }^{35}$ the latter brought the discourse to the academia through his inaugural lecture. ${ }^{36}$

31 W Mignolo 'Delinking: The rhetoric of modernity, the logic of coloniality and the grammar of decoloniality' (2007) 21 Cultural Studies 463.

32 K Klare 'Legal culture and transformative constitutionalism' (1998) 14 South African Journal on Human Rights 146.

33 Klare (n 32) 150.

34 K M'baye 'Le droit au development comme un droit de I'homme' (1972) 5 Revue International des Droits de l'Homme cited in OB Okafor 'A regional perspective: Article 22 of the African Charter on Human and Peoples' Rights' 347 http:// hdr.und.org/eng/humandev/ (accessed 25 August 2018).

35 Okafor (n 34).

36 As above. 
What the right to development means remains, at an international level, a subject of geo-political contestation. ${ }^{37}$ For M'baye development has a human dimension that can be 'moral, spiritual and [even] material' ${ }^{38}$ and, moreover, it is an inalienable right that all must benefit from. ${ }^{39}$ This suggests a legal duty and a reciprocal right to moral, spiritual and material development. The African Charter on Human and Peoples' Rights (African Charter) was the first regional instrument to make the right to development a justiciable right for member states. The other notable regional instrument that makes provision for the right to development as legally binding is the 2004 Arab Charter. ${ }^{40}$ Article 22 of the African Charter states that all peoples 'shall have the right to their economic, social and cultural development with due regard to their freedom and identity and equal enjoyment of the common heritage of mankind' and all states 'shall have the duty, individually and collectively, to ensure the exercise of the right to development'.

At the international level the right to development has received several pronouncements, for example, in the 1986 United Nations Declaration on the Right to Development (RTD Declaration); the 1993 Vienna Declaration and Programme of Action; and the 2000 United Nations Millennium Declaration. ${ }^{41}$ However, all these international declarations constitute 'soft' law or non-binding law. While the second part highlights the duty bearers of the right, the first part of article 22 underlines its composite nature which comprises socioeconomic and cultural as well as freedom or civil and political rights.

I have already indicated that for Klare the idea of transformative constitutionalism inheres in the fact that the Constitution a priori is transformative in that it in itself is committed to large-scale changes of political and social institutions and power relations in society. For Gutto the right to development is implicit in the Constitution. Notions such as public participation in the affairs of the state, references to sustainable development and the right to self-determination should be read as implicit incorporation of the right to development in the Constitution. $^{42}$ In this sense, according to Gutto, the right to development suffuses the entirety of the Constitution as the Constitution is a developmental document in and of itself. ${ }^{43}$ For Gutto

37 K Arts \& A Tamo 'The right to development in international law: New momentum thirty years down the line?' (2016) 63 International Law Review 224; M'baye (n 34) in S Kamga 'The right to development in the African human rights system: The Endorois case' (2011) 49 De Jure 383.

38 M'baye (n 34) in Kamga (n 37) 384.

39 Okafor (n 34) 347.

40 Article 2 of the Arab Charter on Human Rights (2004).

41 Arts \& Tamo (n 37) 224.

42 S Gutto 'The right to development: An implied right in South Africa's constitutional order' (2006) in 'Reflections on democracy and human rights: A decade of the South African Constitution' 113 http://www.sahrc.org.za (accessed 22 July 2018). 
'the national development strategies and objectives point to a model of a developmental state regime that sits comfortably with its right to development'. ${ }^{44}$ The fact that South Africa has ratified a number of regional and international legal instruments that entrench the right to development, according to Gutto, is further evidence of the implicit presence of the right to development in the Constitution.

I suggest that while there have been attempts to find 'the transformative' and 'the developmental' in the Constitution, there have been negligible attempts to find a possible nexus between transformative constitutionalism and the right to development. It is in this context that I propose a vertical reading of the relationship between transformative constitutionalism and the right to development, with transformative constitutionalism being an attempt to give concrete expression to the right to development. This vertical relationship, wherein transformative constitutionalism is read as a concrete expression of the right to development, inheres in that the right to development has an international dimension whereas transformative constitutionalism largely is circumscribed to how the South African Constitution should be observed.

The vertical confluence between the right to development and transformative constitutionalism inheres in that both discourses envisage large-scale change that is developmental and occurs within the context of legal rights. In this sense the motive is change that is developmental and the method appropriated for this change is law and constitutionalism occasioned by the state in a participatory manner.

The notion of change, development and progress of society that is grounded in law invites the question posed earlier: If transformative constitutionalism and the right to development can be implicated within the structures of legal modernity, and there exists a relationship between modernity and colonialism, how do we maintain faith in their capacity to bring about radical transformation?

In his foreword to Fanon's 2008 edition of Black skin white mask, Sardar posits the following thesis: 45

If Western civilisation and culture are responsible for colonial racism, and Europe itself has a racist structure, then we should not be surprised to find this racism reflected in the discourses of knowledge that emanate from this civilisation and that they work to ensure that structural dominance is maintained.

Nandy also deals with the question of whether it is possible to 'defeat the West on the strength of one's acquired Westernness' and 'if beating the West at its own game is the preferred means of handling the feelings of self-hatred in the modernised non-West'. ${ }^{46}$ For our

44 Gutto (n 42) 113.

45 Z Sardar 'Foreword to the 2008 edition' in Fanon (n 4) xv.

46 Nandy (n 15) xiii. 
purposes the two interrelated questions that arise out of the theses of Nandy and Sardars are whether it is possible to attain radical transformation using the law in the form of (transformative) constitutionalism and the language of human rights or the right to development. For Nunn,

what has come to be known as 'the law' in Western societies is really a particular social construction that exhibits cultural attributes peculiar to European and European-derived societies. Law is an artifact of a Eurocentric culture, and as such it reflects the cultural logic, epistemology, axiology, ontology, ethos and aesthetic choice of Eurocentric culture. The core attributes of Eurocentricity are readily discernible within the law. ${ }^{47}$

This is so because law is a result of a particular set of historical realities and mindsets. ${ }^{48}$ In this sense law, according to Nunn, is a Eurocentric enterprise. The discernible Eurocentric attributes that are found in law, according to Nunn, are dichotomous reasoning, analytical thought, employment of hierarchies, objectification, abstraction and desacrilisation. ${ }^{49}$ It is these attributes that have spawned successive Eurocentric jurisprudential approaches, including natural law and positivism, which remain dominant up to today. ${ }^{50}$ Most importantly, Western law has allowed for the dominance of Eurocentric culture and, by implication, Eurocentric epistemology.

According to Fitzpatrick, there exists a very pervasive view that 'law, if used alright, can bring about development or modernisation, or it can secure an order in which other transforming agents can operate'. ${ }^{51}$ Contrary to the latter view, Fitzpatrick is of the view that Western law actually has been integral to the denial of being of the peoples of the Third World and this denial is the essence of the constitution of Western law itself. ${ }^{52}$

The implication of Nunn's observations is that Eurocentric epistemology, which thrives on dominance, is an intrinsic part of Western law. The question that arises, based on Nunn's observation and raised by Sardar, Nandy and Fitzpatrick, is whether, if law is a Eurocentric enterprise, what are the prospects of it being employed in the service of radical transformation - that is, if we view radical transformation as fundamentally about the disruption of coloniality.

The notion of transformative constitutionalism is centred on constitutionalism's central's tenet which is the rule of law. The discourse around the right to development, with a few exceptions, pivots around the notion of progress and historicism. The rule of law and the notion of development themselves pivot around the notions

47 K Nunn 'Law as a Eurocentric enterprise' (1997) 15 Law and Inequality 350.

48 As above.

49 Nunn (n 47) 334-337.

50 Nunn (n 47) 339-343.

51 P Fitzpatrick 'Law's infamy' in P Fitzpatrick Law as resistance (2008) 43.

52 Fitzpatrick (n 51) 42. 
of periodisation, itself an offshoot of Hegelian theodicy and Marxian dialectics.

I suggest that the dominant enthusiastic appropriation of Klare's notion of transformative constitutionalism has paid scant regard to Klare's overarching theoretical framework which fundamentally is anchored in his constitutive theory of law which in turn is informed by Marxist humanism. ${ }^{53}$ The essence of Klare's constitutive theory of law is faith in law in that it is possible to fill the law with humane content, $^{54}$ and that legal culture can provide a context and a moral basis for resistance to injustice. ${ }^{55}$ This approach arguably is writ large in the notion of transformative constitutionalism as conceived by Klare. In other words, there are palpable parallels between the notion of transformative constitutionalism and the constitutive theory of law wherein the focus is on law making as praxis.

If radical transformation inheres in the identification of Eurocentric culture and values as embedded in the law and constitutionalism, transformative constitutionalism and the notion of development, and if Eurocentric culture is used as a site for the domination of the other, and if in accordance with Fitzpatrick the denial of being of the Third World peoples is 'integral to the constitution of Western law itself', 56 their ability to bring about radical transformation becomes suspect. Sibanda argues that the major pitfall of transformative constitutionalism is that it is embedded within a liberal-democratic paradigm. He points out that

the prevalence of a liberal democratic constitutional discourse - despite the best intentions of transformative constitutionalism - has had the effect of defining the goods of constitutionalism in narrower terms ... it is transformative constitutionalism's ostensible weddedness to liberal democratic constitutionalism that makes it ill-suited for achieving the social, economic and political vision it proclaims.

For Sibanda legal culture and the prevailing liberal-democratic paradigm in South Africa are two major factors implicated in the threat to transformative constitutionalism and implicitly the right to development. In this sense the threat to transformative constitutionalism is to be found within the neo-liberal trajectory that houses transformative constitutionalism.

According to Sibanda, not only is 'the traditionalism and conservatism of South African legal culture a threat to transformative constitutionalism'. ${ }^{58}$ The fact that the Constitution structurally and

53 S Levinson 'Escaping liberalism: Easier said than done' (1983) 96 Harvard Law Review 1474.

54 K Klare 'Law-making as praxis' (1979) 40 Telos 133.

55 As above.

56 Fitzpatrick (n 51) 42.

57 S Sibanda 'Not purpose-made! Transformative constitutionalism, postindependence constitutionalism and the struggle to eradicate poverty' in S Liebenberg \& G Quinot (eds) Law and poverty (2012) 44. 
institutionally accords with the basic tenets of liberal democratic constitutionalism (a few innovations notwithstanding) presupposes that transformative constitutionalism essentially is attainable through sustained and purposeful legal and judicial interpretation demanding shared consciousness. ${ }^{59}$ Van Marle also suggests the possibility that 'constitutionalism and human rights discourse are post-apartheid South Africa's embrace of the light of the Western world'.60

The right to development in the African Charter, as much as it is considered to have 'highly significant African roots', 61 faces obstacles particularly if it is juxtaposed with post-colonial and de-colonial approaches. Because the notion of development is said to be a natural mutation of Enlightenment philosophy ${ }^{62}$ and historicism, I suggest that the post-colonial and de-colonial critiques levelled against Eurocentric historical and historiographical narratives equally apply to the notion of development. In this sense, the notion of development would be imbricated in European universalism and, therefore, be provincial and ethnocentric. This view is buttressed by Escobar who argues that the notion of development constitutes a regime of representation wherein Africa and other Third World countries are constructed in European terms. ${ }^{63}$ In other words, how Africa makes sense of itself largely is determined in terms of Western structures of thought. In this sense, Africa's sense of self and aspirations become locked in and therefore correspond to the wishes, aspirations and needs of others, thereby becoming enframed in European reality. ${ }^{64}$

However, for De Sousa Santos it is possible to appropriate the language of human rights, and by implication the language of law and 'place it at the service of a progressive, emancipatory politics' ${ }^{65}$ In this sense De Sousa Santos effectively is suggesting a counterhegemonic conception of human rights and, by implication, the possibility of using the right to development 'counter-hegemonically'. The debate about the place of human rights in the developing world, according to De Sousa Santos, properly is a question of the universality of human rights. However, for De Sousa Santos,

the question about the universality of human rights is a western cultural question ... hence human rights are universal only when they are viewed from a Western standpoint. The question of the universality of human rights betrays the universality of what it questions by the way it questions

59 Sibanda (n 57) 51.

60 K van Marle 'The spectacle of post-apartheid constitutionalism' (2014) 16 Griffiths Law Review 414.

61 Okafor (n 34) 373.

62 A Escobar Encountering development: The making and unmaking of the Third World (1995).

63 Escobar (n 62) 7.

64 As above.

65 B de Sousa Santos 'Human rights as an emancipatory script? Cultural and political conditions' in De Sousa Santos (n 12) 3. 
it. In other words, the question of universality is a particular question, a Western cultural question. ${ }^{66}$

It is possible to read De Sousa Santos as suggesting that the very question of whether law and human rights can be used as emancipatory tools in the service of radical transformation itself is not an original question but a question that itself is perfidiously colonial. The fact that there exists different inter-continental human rights systems already is an indication of the pluriversal conception of human rights, and the right to development is one such pluriversal right that can be conceived of in a differentiated ${ }^{67}$ manner. In same manner as Sibanda, De Sousa Santos suggests that 'only if a politics of human rights radically different from the hegemonic liberal one is adopted and only if such a politics is conceived as part of a broader constellation of struggles and discourses of resistance and emancipation rather than as the sole politics of resistance against oppression'68 can the possibilities that abound in human rights language be attained.

The question is whether De Sousa Santos effectively deals with the notions of what de-colonial theorists call 'the Western code' and coloniality embedded in Eurocentrism. Put differently, and borrowing from Ndlovu-Gatsheni, if coloniality 'is the name of the darker side of modernity that needs to be unmasked because it exists as an embedded logic that enforces control, domination, and exploitation disguised in the language of salvation, progress, modernisation', ${ }^{69}$ is it possible to dredge out human rights from Eurocentrism? If human rights are implicated in what Mignolo refers to as the Western code, the Western code which means 'the unity of liberal thought', ${ }^{70}$ which only allows for one truth that is guaranteed by violence, is it still possible to 'pluriversalise' the essence of 'universal human rights' without re-inscribing their Eurocentric structures as suggested by De Sousa Santos?

It is in this sense that I suggest that while the right to development and transformative constitutionalism creates conditions conducive to the attainment of radical transformation, they may not in themselves bring about the radical transformation that we envisage.

66 De Sousa Santos (n 12) 12.

67 CC Ngang 'Differentiated responsibilities under international law and the right to development paradigm for developing countries' (2017) 2 Human Rights and International Legal Discourse 265.

68 De Sousa Santos (n 12) 3.

69 S Ndlovu-Gatsheni 'Why de-coloniality in the 21st century' (2013) 48 The Thinker 13.

70 Mignolo (n 9) xvii. 


\section{Conclusion}

In this article I have agreed with Mbembe's allegorical representation, using South Africa as an example, that Africa indeed is possessed of the highest power of language, on the one hand, and, on the other, that Africa represents the impotence of the speaker who is unable to state the sense of what he or she says, and unable to at the same time 'say something and its meaning'. In line with this allegorical representation, I argue that the language of radical transformation, devoid of historicist and positivist tendencies, offers elbow room for Africa to use the power of language that it possesses which in turn will create fecund possibilities for Africa to 'say something and its meaning'. I have argued that the disruption of coloniality is fundamental to the project of radical transformation.

I have also contended that considering the deep ontological and epistemic impact that colonialism and apartheid have had on the African continent as a whole, the project of radical transformation can only inhere in the disruption of coloniality. The disruption of coloniality in this sense requires challenging parochial European historical and historiographical narratives. I have further suggested that the core attributes of Eurocentricity are discernible in law, and this because of the fact of law being a result of a particular set of historical realities, cultural traits and mind-sets. ${ }^{71}$ I therefore tentatively conclude that the essence of the project of radical transformation should pivot on the disruption of coloniality, and this approach necessarily suggests that radical transformation can only be characterised by rupture.

71 Nunn (n 47 above) 350. 